\title{
What is the evidence for a causal link between hygiene and infections?
}

\author{
Allison E Aiello and Elaine L Larson
}

Even in an era in which access to personal "cleanliness" and a public health infrastructure are readily available in developed countries, illnesses associated with day care centres and homes continue to be a problem. The inhabitants of less developed countries, on the other hand, must contend with an inadequate public health infrastructure, lack of education programmes, and economic limitations in obtaining hygiene products. Therefore, less developed countries carry a greater burden of morbidity and mortality from infectious illnesses. The objective of this review is to examine and assess the epidemiological evidence for a causal relation between hygiene practices and infections. The Medline database was searched from January 1980 to June 2001 and studies were included if the outcome(s) was infection or symptoms of infection, and if the independent variable(s) was one or more hygiene measures. The strength of the association as measured by the relative reduction in risk of illness was appreciable and generally greater than $20 \%$. Despite methodological strengths and limitations of the studies assessed, the weight of evidence collectively suggests that personal and environmental hygiene reduces the spread of infection. The results from this review demonstrate that there is a continued, measurable, positive effect of personal and community hygiene on infections.

Lancet Infectious Diseases 2002; 2: 103-110

\section{Introduction}

Over the past century, hygiene improvements at the individual and community level such as sanitary living conditions and practices, potable water, and sewage facilities, have had a major role in reducing morbidity and mortality from infections (figure), particularly those transmitted by the faecal-oral and direct contact routes. Even in developed countries where there is access to improved water supply and sanitation, such infections continue to be a problem, especially in high-risk settings in which susceptible individuals gather such as child-care and elder-care centres. In developing countries, infections carry an even greater burden of morbidity and mortality, especially in areas where public health infrastructure and medical care are inadequate or unavailable. At the beginning of 2000, approximately 1 billion individuals globally lacked adequate water supply and more than 2 billion lacked access to adequate sanitation. Most people who do not have access to these basic infrastructures live in developing countries. ${ }^{1}$

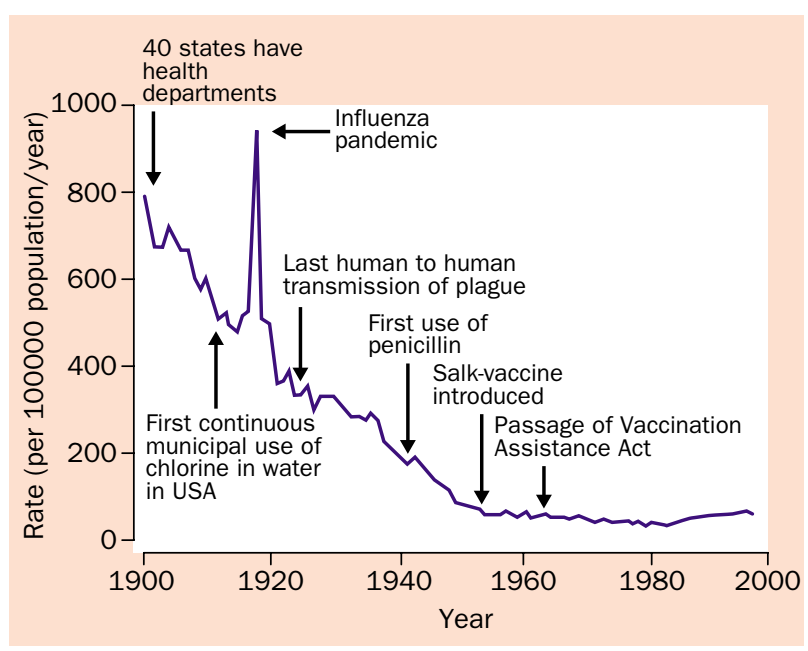

Crude death rate for infectious diseases, USA, 1900-1996. Adapted from: Achievement in public health, 1900-1999: control of infectious diseases. MMWR Morb Mortal Wkly Rep 1999; 48: 621-29; and Armstrong GL, Conn LA, Pinner RW. Trends in infectious disease mortality in the United States during the 20th century. JAMA 1999; 281: 61-66.

It is well established that general improvements in personal hygiene practices and public health infrastructure can reduce certain infections. ${ }^{2-5}$ The Global Water Supply and Sanitation Assessment 2000 Report provided by WHO, lists three key hygiene behaviours that are of greatest likely benefit to health, particularly in developing countries: (1) handwashing with soap (or ash or other aid), (2) safe disposal of children's faeces, and (3) safe water handling and storage.

However, the extent to which risk is reduced by a specific hygiene practice alone, such as handwashing, or in combination remains unknown. In a comprehensive review of the impacts of improved water supply and sanitation on infections published in 1991, Esrey et $\mathrm{al}^{4}$ concluded that the availability of water for personal and domestic hygiene and safe excreta disposal has a greater impact on health than improved drinking water quality alone. Therefore, they called for future research examining specific hygiene behaviours or practices that would provide the greatest benefit to health. ${ }^{4}$

AEA is a doctoral student in epidemiology at the Joseph L Mailman School of Public Health, Columbia University, New York, NY, USA; and ELL is professor of Pharmaceutical and Therapeutic Research, Columbia University School of Nursing.

Correspondence: Professor L Elaine Larson, Columbia University School of Nursing, 630 W 168th Street, New York, NY10032, USA. Tel +1 212305 0726; fax +1212305 0722;

email Ell23@columbia.edu 
The aims of this review are to: (1) examine the epidemiological evidence for a relation between hygiene practices (other than broad public health measures alone) and infections; (2) provide a summary of the specific hygiene measures and infectious outcomes that have been the focus of published research for the past 20 years; (3) discuss the magnitude of reduction in infections attributed to specific hygiene interventions; and (4) examine the epidemiological strengths and limitations of the studies in order to highlight future research needs.

\section{Methods}

The Medline database was searched for articles published during the period January 1980 to June 2001 with keywords including "hygiene", "health", "sanitation", "soap", "washing", "handwashing", "community", "infection", "infectious illnesses", "diarrhoea", and "day care". Additional papers were obtained by searching the reference lists in the retrieved papers. Articles were included in the review if the outcome(s) was infection or symptoms of infection and if the independent variable(s) was one or more hygiene measures. Hygiene measures were defined as any method of hygiene that was not based solely on infrastructure or implementation of facilities, such as municipal water supply and waste disposal. Articles were restricted to those written in the English language and employing either interventional or observational designs. The study design was categorised as an interventional study if the design was either experimental (formally randomised) or quasi-experimental (non-randomised intervention assignment). All studies that lacked implementation of an intervention were considered observational. Articles were excluded if the hygiene measures were solely public health infrastructure and/or systems such as municipal water supply and waste disposal, or if the setting was a healthcare facility, such as a hospital or residential nursing home. The strengths and limitations of the intervention studies were assessed by considering methods related to conduct and design, such as use of randomisation, assessment and control of confounding factors, blinding, and other pertinent validity issues.

\section{Findings}

There were 30 interventional and 24 observational studies during the 20.5 year period (tables 1 and 2). One study ${ }^{19}$ included an observational component in an intervention study.

\section{Intervention studies}

Of the 30 intervention studies, 11 were conducted in the USA (37\%), two in Canada (7\%), two in Australia (7\%), and $15(52 \%)$ were in less-developed countries (table 1). The studies from the USA were predominantly in day care centres or school settings $(10 / 11,91 \%)$ and one study was done in an elder-care center. All studies in Australia and Canada were done in schools or day care centres. Studies from less-developed countries were conducted primarily within the community or among families and one study was set in a refugee camp.

Hygiene education was the most common intervention $(23 / 30,77 \%)$ followed by various handwashing practices
$(6 / 30,20 \%)$. Infrastructure interventions that were used in combination with either education or handwashing interventions, included improving potable water supply $(5 / 30,17 \%)$ and construction of a latrine $(1 / 30,3 \%)$. Less than half of the studies used a combination of various intervention methods mentioned in table 1 (13/30, 43\%). Most of the studies examined diarrhoea or gastrointestinal illness as at least one of the main outcomes (24/30, 80\%). Other outcomes included respiratory infections, skin infections, trachoma, flu-like symptoms, otitis, sinusitis, and absences from school due to symptoms of infection (13/30, $43 \%)$. In general, the reduction in all infectious disease symptoms and infections was appreciable, greater than $20 \%$ for most hygiene interventions. Two studies (2/30, 7\%) found no reduction in diarrhoea illnesses after the implementation of hygiene educational interventions (table 1) ${ }^{6,7}$

\section{Observational studies}

One observational study was conducted in the USA (4\%), and 23 in developing countries (96\%; table 2). The US study focused on home-based day care providers. The majority of the studies conducted in developing countries examined practices within the family, household, and community. However, two studies occurred in day care centres and one involved Australian military personnel treating Kurdish refugees in Iraq. ${ }^{50,51,56}$ Most of the studies created hygiene indicator variables that encompassed behaviour (ie, handwashing, infant and children feeding practices, and diapering practices), knowledge (ie, risk behaviours, transmission routes and/or methods of prevention), and/or personal and environmental cleanliness (ie, observations of hand or facial cleanliness, faecal disposal practices, refuse disposal, food handling, and/or general household hygiene).

Diarrhoeal illness was the most common health outcome studied (19/24, 79\%). Other illnesses examined included trachoma $(3 / 24,12 \%)$, respiratory illness $(2 / 24$, $8 \%)$, and helminth infection $(1 / 24,4 \%)$. All but two of the studies $^{19,44}$ found a correlation between hygiene variables and a reduction in infection. Araya et $\mathrm{al}^{19}$ reported no association between improved hygiene habits and decrease in risk of developing diarrhoea. A cross-sectional study by Moy et $\mathrm{al}^{44}$ reported no association between diarrhoeal morbidity and factors such as use of unprotected water source, inadequate toilet facilities, and living conditions. They concluded that differences not measured at the individual level, such as hygiene behaviour and individual susceptibility to diarrhoea, may have explained the null results.

\section{Discussion}

The 53 studies published from 1980-2001 which examined hypotheses regarding hygiene and health indicate a strong trend toward appreciable reductions of infection after implementation or changes in hygiene measures or behaviours. The reduction in risk of infections was greater than $20 \%$ for most of the interventions, and most of the observational studies reported a strong association between risk factors associated with inadequate hygiene and infection.

In less-developed countries, the association between hygiene and health was examined mainly on the community 
Table 1. Intervention studies assessing effects of hygiene on infections, 1980-June 2001

\section{Author, year Type of intervention/setting/country \\ Black et al, 19816 Handwashing with soap/child care centres/USA \\ Khan, 1982 $\quad$ Handwashing with soap, water container and water supplied/families/Bangladesh \\ Torun, $1982^{8} \quad$ Water supplied and hygiene education/ villages/Guatemala}

Stanton and Clemens, $1987^{\circ}$

Hill et al, $1988^{10}$

Bartlett, $1988^{11}$

Han and Hlaing $1989^{12}$

Hygiene education /communities/Bangladesh

Hygiene education/community/Philippines Hygiene education/day care centres/USA

Alam et al, 1989 ${ }^{13}$ Water supplied and hygiene education/ community/Bangladesh

Aziz et al, 1990'4 Water supplied, hygiene education, and latrine built/community/Bangladesh

Butz et al, 1990 ${ }^{15}$ Alcohol hand rinse, hygiene education, gloves, diaper changing pads/day care vinyl centres/USA

Wilson et al, $1991^{16}$ Handwashing with soap supplied and hygiene education/community/Indonesia

Monsma et al, Handwashing with soap and hygiene $1992^{17} \quad$ education/school/Canada

Ahmed et al, $1993^{18}$ Hygiene education/community/Bangladesh Araya et al, $1994^{19}$ Hygiene education/family/Chile

Haggerty et al, Hygiene education/community/Zaire $1994^{20}$

Kotch et al,1994 $4^{21}$ Hygiene education/day care centres/USA

West et al, 199522 Hygiene education/community/Tanzania Mohle-Boetani et al, Handwashing with soap supplied and $1995^{23} \quad$ hygiene education/community outbreak/USA

Shahid et al, Handwashing with soap supplied and 1996 ${ }^{24} \quad$ water container/community/Bangladesh

Pinfold and Horan, Handwashing with soap supplied and $1996^{25} \quad$ hygiene education/community/Thailand Krilov et al, $1996^{26}$ Hygiene education/school/USA

Kimel, 1996 $\quad$ Handwashing with soap and hygiene education/school /USA

Niffenegger, Handwashing with soap and hygiene $1997^{28} \quad$ education/schools/USA

Master et al, Handwashing with soap/school/USA $1997^{29}$

Peterson et al, Handwashing with soap supplied/ $1998^{30} \quad$ refugee camp/Malawi

Carabin et al, Hygiene education/child care $1999^{31} \quad$ centres/Canada

Falsey et al, 1999 ${ }^{32}$ Hand sanitising with alcohol foam supplied and hygiene education/adult day care centres/USA

Roberts et al, Hygiene education/child care

$2000^{33} \quad$ centres/Australia

Roberts et al, Same as above

$2000^{34}$

Dyer et al, 2000 35 Hand sanitising product supplied/ school/USA

\section{Results}

$67 \%$ reduction in risk of Shigella sp secondary infection, $p<0 \cdot 01$

Study 1: no differences between villages in diarrhoeal, respiratory, skin infections, and other infectious diseases. Study 2: diarrhoeal disease appreciably lower among intervention children ages 0-24 months

$26 \%$ reduction in risk of diarrhoea in children age $<6$ years in intervention area vs control area

$70 \%$ decrease in diarrhoea and fever per 2 -week period among children age $<6$ years $30 \%$ decrease in incidence of diarrhoea among children in intervention homes No significant appreciable differences in rates of diarrhoea for preintervention vs post-intervention

Odds of having none or one episode of diarrhoea was significantly lower for children living in households using three or four hygiene practices compared with none or only one practice $25 \%$ fewer episodes of diarrhoea and $30 \%$ reduction in dysentery among children in intervention area

$28 \%$ lower risk of diarrhoea days in intervention homes vs controls, $95 \% \mathrm{Cl}(0 \cdot 54-0 \cdot 72)$ $66 \%$ lower risk of vomiting days in intervention day care homes vs controls, $95 \% \mathrm{Cl}(0 \cdot 20-0 \cdot 56)$. No appreciable significant reduction in runny nose $89 \%$ and $45 \%$ reduction in episodes of diarrhoea and skin/eye diseases, respectively, among children in intervention community

$22 \%$ less absenteeism, $25 \%$ less visits to the physician, and $86 \%$ less medications used compared with previous year

Reduction in diarrhoea morbidity at intervention site

Approximately 10 mean days of diarrhoea among children in the intervention group vs 14 in the control group, $p<0 \cdot 01$. No appreciable significant decrease in persistent diarrhoea in intervention vs control group

$11 \%$ reduction in risk of reporting diarrhoea during the peak diarrhoeal season in intervention areas vs controls, $95 \% \mathrm{Cl}(0.85-0.98)$. Mean number of diarrhoea episodes among children (3-35 months of age) 1 year after baseline in intervention area was 0.85 vs 0.90 in control; difference was not statistically significant

After adjustment, $46 \%$ reduction in episodes of severe diarrhoea in intervention classrooms vs controls, $95 \% \mathrm{Cl}(0 \cdot 03-1 \cdot 04)$. No statistically significant differences in any other illnesses After adjustment, $38 \%$ lower risk of severe trachoma in intervention village vs control 42 shigella cases in June vs 10 after intervention implementation in July

$62 \%$ reduction in primary and secondary cases of diarrhoea combined and all pathogens analysed in intervention vs control area, $95 \% \mathrm{Cl}(0.33-0.43)$

$39 \%$ overall reduction in risk of diarrhoea in children $<5$ years in intervention vs control area, $\mathrm{p}<0.05$

Compared with baseline, there was a decrease in median number of total illnesses per month from 0.70 to 0.53 in children 6 weeks to age $5, p<0.05$ $1 \cdot 8 \%$ of students ill per day in intervention classes vs $3.8 \%$ in control classes, $p=0.001$

Weeks 1 through 11: $9 \cdot 4 \%$ of students age $3-5$ in intervention school had colds vs $12.7 \%$ in control, $p<0.05$. Weeks 12 through $21: 18.9 \%$ of students in intervention school had colds vs $27.8 \%$ in control, $p<0.05$ $25 \%$ reduction in days of absences due to all communicable illnesses, $p=002$. $21 \%$ reduction in days of absences due to respiratory illness in handwashing group vs control, $p=0.02 .57 \%$ reduction in days of absences due to gastrointestinal illness in handwashing group vs control, $\mathrm{p}=0.07$

$27 \%$ reduction in risk of diarrhoea in households with soap vs no soap, $95 \% \mathrm{Cl}$ (0.54-0.98)

No appreciable reduction in incidence rate of diarrhoea or upper respiratory infections from pre to post-intervention

$50 \%$ reduction in respiratory infection rate in adult day care attendees associated with education programme for staff members

After adjustment, $15 \%$ reduction in rate of absence from respiratory infection in intervention centres vs controls, 95\% Cl (0.55-1.11)

After adjustment, $50 \%$ reduction in rate of absence from diarrhoea in intervention centres vs controls, $95 \% \mathrm{Cl}(0 \cdot 36-0 \cdot 68)$

$28.9 \%$ and $49 \cdot 7 \%$ reduction in risk of gastrointestinal and respiratory-related illnesses, respectively, in children in intervention group vs control 
Table 2 Observational studies assessing effects of hygiene on infections, 1980-June 2001

\begin{tabular}{|c|c|c|}
\hline Author, year & Risk factors examined/study design/country & Results \\
\hline $\begin{array}{l}\text { Bertrand and } \\
\text { Walmus, } 1983^{36}\end{array}$ & $\begin{array}{l}\text { Maternal knowledge and attitudes/cross- } \\
\text { sectional/Colombia }\end{array}$ & $\begin{array}{l}\text { Raised prevalence of diarrhoea significantly associated with child malnutrition, age } \\
\text { of mother, house appearance, maternal birthplace, mother's } \\
\text { general knowledge of diarrhoea }\end{array}$ \\
\hline $\begin{array}{l}\text { Stanton and } \\
\text { Clemens, } 1985^{37}\end{array}$ & $\begin{array}{l}\text { Handwashing and home hygiene practices/ } \\
\text { case-control/Bangladesh }\end{array}$ & $\begin{array}{l}\text { Significantly less maternal handwashing and more disposal of } \\
\text { excreta on floor in controls versus cases }\end{array}$ \\
\hline $\begin{array}{l}\text { Araya et al, } 1994^{19} \\
\text { Baltazar and Solon, } \\
1989^{38}\end{array}$ & $\begin{array}{l}\text { Hygienic practices in family/cross-sectional/Chile } \\
\text { Disposal of faeces/case-control/Philippines }\end{array}$ & $\begin{array}{l}\text { Adequate hygienic habits associated with increased of diarrhoea } \\
\text { Clinically diagnosed diarrhoea was significantly associated with a } \\
34 \% \text { increase with unsanitary disposal of children's stools }\end{array}$ \\
\hline $\begin{array}{l}\text { Taylor et al, } \\
1989^{39}\end{array}$ & $\begin{array}{l}\text { Facial cleanliness and other hygiene-related risk } \\
\text { factors/cross-sectional/Tanzania }\end{array}$ & $\begin{array}{l}\text { Poor facial cleanliness and household fly density was significantly } \\
\text { associated with an increased risk for trachoma }\end{array}$ \\
\hline $\begin{array}{l}\text { Henry and Rahim, } \\
1990^{40}\end{array}$ & $\begin{array}{l}\text { Contamination of children's hands and drinking } \\
\text { water/cross-sectional/Bangladesh }\end{array}$ & $\begin{array}{l}\text { Diarrhoea rates significantly lower with more sanitation and water } \\
\text { contamination and correlated with degree of contamination of hands }\end{array}$ \\
\hline $\begin{array}{l}\text { Yeager et al, } \\
1991^{41}\end{array}$ & $\begin{array}{l}\text { Personal and environmental hygiene/cross- } \\
\text { sectional/Peru }\end{array}$ & $\begin{array}{l}\text { Water storage, location of child defecation, child eating soil or } \\
\text { faeces, young age were significant predictors of diarrhoea }\end{array}$ \\
\hline $\begin{array}{l}\text { West et al, } \\
1991^{42}\end{array}$ & $\begin{array}{l}\text { Facial cleanliness and other hygiene related } \\
\text { risk factors/cross-sectional/Tanzania }\end{array}$ & $\begin{array}{l}70 \% \text { higher rate of trachoma in children with flies and nasal } \\
\text { discharge on their faces }\end{array}$ \\
\hline $\begin{array}{l}\text { Ekanem et al, } \\
1991^{43}\end{array}$ & $\begin{array}{l}\text { Home hygiene and environmental factors/ } \\
\text { case-control/Nigeria }\end{array}$ & $\begin{array}{l}\text { Faeces around toilet area, use of chamber pots, indiscriminate waste disposal, } \\
\text { source of domestic water were significantly associated with diarrhoea }\end{array}$ \\
\hline Moy et al, $1991^{44}$ & $\begin{array}{l}\text { Hygiene level and socioeconomic status/ } \\
\text { cross-sectional/Zimbabwe }\end{array}$ & $\begin{array}{l}\text { Higher mean attack rates of diarrhoea were associated with hygiene } \\
\text { level, use of protected water source, toilet facilities, and socioeconomic status. } \\
\text { None of the associations were statistically significant }\end{array}$ \\
\hline $\begin{array}{l}\text { Wijewardene et al, } \\
1992^{45}\end{array}$ & $\begin{array}{l}\text { Home hygiene and education level/ } \\
\text { case-control/Sri Lanka }\end{array}$ & $\begin{array}{l}\text { Lack of piped water and latrine, low level of maternal education and } \\
\text { awareness of disease spread, no disposal of child faeces in latrine, } \\
\text { improper garbage disposal were significantly associated with an } \\
\text { increased risk of diarrhoea in cases versus controls }\end{array}$ \\
\hline $\begin{array}{l}\text { Bartlett et al, } \\
1992^{46}\end{array}$ & $\begin{array}{l}\text { Home hygiene and environmental factors/ } \\
\text { longitudinal/Guatemala }\end{array}$ & $\begin{array}{l}\text { Presence of toy, faecally soiled diaper or baby bottle on ground, dirty } \\
\text { maternal hands, faeces in yard, child wearing faecally soiled diaper } \\
\text { were significantly associated with persistent diarrhoea }\end{array}$ \\
\hline $\begin{array}{l}\text { Baltazar et al, } \\
1993^{47}\end{array}$ & $\begin{array}{l}\text { Personal and domestic hygiene/case-control/ } \\
\text { Philippines }\end{array}$ & $\begin{array}{l}\text { The odds of diarrhoea increased significantly with declining standards } \\
\text { of overall cleanliness and kitchen hygiene but not for living conditions }\end{array}$ \\
\hline $\begin{array}{l}\text { Punyaratabandhu, } \\
\text { et al, } 1993^{48}\end{array}$ & $\begin{array}{l}\text { Hygiene factors in government housing project/ } \\
\text { prospective follow-up study/Thailand }\end{array}$ & $\begin{array}{l}\text { Non-working mothers, unhygienic behaviour of child caretaker such } \\
\text { as no handwashing and method of cleaning milk bottles were } \\
\text { significantly associated with an increased risk in childhood diarrhoea }\end{array}$ \\
\hline $\begin{array}{l}\text { Dikassa et al, } \\
1993^{49}\end{array}$ & $\begin{array}{l}\text { Household cleanliness and caretakers hygiene } \\
\text { knowledge/case-control/Zaire }\end{array}$ & $\begin{array}{l}70 \% \text { higher risk of severe childhood diarrhoea if mothers scored } \\
\text { poorly on disposal of child faeces and household garbage and } \\
\text { knowledge that poor caretaker cleanliness was a cause of diarrhoea }\end{array}$ \\
\hline $\begin{array}{l}\text { Sempertegui et al, } \\
1995^{50}\end{array}$ & $\begin{array}{l}\text { Hygiene factors in child care centres and homes/ } \\
\text { cross-sectional/Ecuador }\end{array}$ & $\begin{array}{l}\text { Reuse of water for child handwashing and washing raw vegetables } \\
\text { was significantly associated with diarrhoea episodes }\end{array}$ \\
\hline $\begin{array}{l}\text { Rudland et al, } \\
1996^{51}\end{array}$ & $\begin{array}{l}\text { Chemoprophylactics, plate, and handwashing in } \\
\text { British and Australian troops/cross-sectional//raq }\end{array}$ & $\begin{array}{l}\text { Not taking doxycycline and having no enforced plate and hand } \\
\text { washing regimen significantly associated with higher diarrhoea rates }\end{array}$ \\
\hline $\begin{array}{l}\text { Ghosh et al, } \\
1997^{52}\end{array}$ & Maternal behaviours/case-control/India & $\begin{array}{l}\text { Bottle feeding, non-use of soap to clean feeding container, open water storage, } \\
\text { drinking pond water, indiscriminate disposal of child faeces were associated } \\
\text { with significantly higher incidence of diarrhoea in case versus control families }\end{array}$ \\
\hline $\begin{array}{l}\text { Oyemade et al, } \\
1998^{53}\end{array}$ & $\begin{array}{l}\text { Environmental and personal hygiene practices/ } \\
\text { cross-sectional/Nigeria }\end{array}$ & $\begin{array}{l}\text { Water and food bought from vendors, child defecation practices, } \\
\text { mothers' cleaning up after child defecation, refuse disposal were } \\
\text { significantly associated with diarrhoea in children }\end{array}$ \\
\hline $\begin{array}{l}\text { St Sauver et al, } \\
1998^{54}\end{array}$ & $\begin{array}{l}\text { Hygienic practices in families and group day } \\
\text { care homes/cross-sectional/USA }\end{array}$ & $\begin{array}{l}\text { Infrequent handwashing significantly associated with higher rates of } \\
\text { respiratory illness }\end{array}$ \\
\hline $\begin{array}{l}\text { Gorter et al, } \\
1998^{55}\end{array}$ & $\begin{array}{l}\text { Hygiene practices/prospective follow-up study/ } \\
\text { Nicaragua }\end{array}$ & $\begin{array}{l}\text { Washing of hands, domestic cleanliness, and use of diapers by children } \\
\text { was protective for diarrhoea }\end{array}$ \\
\hline $\begin{array}{l}\text { Barros et al, } \\
1999^{56}\end{array}$ & $\begin{array}{l}\text { Hygiene practices in child care centres/ } \\
\text { prospective follow-up/cross-sectional/Brazil }\end{array}$ & $\begin{array}{l}33 \% \text { less diarrhoea in classes where soap was frequently used during } \\
\text { diapering. None of the risk factors examined were associated with } \\
\text { respiratory infections }\end{array}$ \\
\hline Scolari, $2000^{57}$ & Home hygiene practices/cross-sectional/Brazil & $\begin{array}{l}\text { Statistically significant correlation between helminth infections and most } \\
\text { housing/hygienic variables }\end{array}$ \\
\hline $\begin{array}{l}\text { Pruss and Mariotti, } \\
2000^{58}\end{array}$ & $\begin{array}{l}\text { Hygiene factors related to trachoma/review of } \\
19 \text { studies/39 parts of the world }\end{array}$ & $\begin{array}{l}\text { Clear evidence to support facial cleanliness and environmental } \\
\text { improvements to prevent trachoma }\end{array}$ \\
\hline
\end{tabular}

level, especially in areas where infrastructure is lacking and high rates of morbidity and mortality from diarrhoeal disease in infants is present. However, it is difficult to examine the incremental effects of specific personal and environmental hygiene measures in less-developed countries since these measures are often combined with newly implemented public health infrastructure and/or systems such as municipal water supply and waste disposal. In developed countries, on the other hand, the widespread availability of public health infrastructure in combination with differing practices and use of cleaning and hygiene products make it difficult to detect added benefits related to 
improvements in personal hygiene at the community level. Therefore, since potable water, waste disposal, and cleaning and hygiene products are readily available in the USA and other developed countries, research has focused on specific groups more susceptible to infections and/or exposed to lower levels of hygiene, such as children in child-care centres and schools.

Our review follows three earlier reviews of studies that included interventions other than hygiene practices alone. ${ }^{3,459}$ In 1983, Feachem ${ }^{59}$ published a comprehensive review of studies linking hygiene and health. This review included studies examining both infrastructure interventions, such as sanitation facilities, and other personal hygiene related risk factors. He summarised the literature from 1929-1981 in a table, but did not discuss in any detail the strengths and limitations of the studies. Following this review, Esrey et $\mathrm{al}^{3}$ published a review of the literature from 1950-1986 on the health benefits from improved water and sanitation. In their review, criteria akin to our list of strengths and limitations were used to evaluate the internal validity of the selected studies. Similar to our findings, none of the studies in the review by Esrey et al were without methodological limitations. Although their review included three of the same references as ours, ${ }^{6-8}$ Esrey et al did not assess the internal validity of these studies since their review was primarily concerned with examining the impact of improved water and sanitation facilities. Esrey et al published a second review in $1991,{ }^{4}$ which focused on the effects of improved water supply and sanitation on several infectious diseases. This subsequent review of the literature, from 1966 to 1986, included only six studies ${ }^{6-9,12,13}$ examining the impact of hygiene interventions on diarrhoeal morbidity. In their review, Esrey et $\mathrm{al}^{4}$ calculated a 33\% median reduction in diarrhoea based on the six hygiene intervention studies. Like the other two earlier reviews, this one did not provide a discussion of the specific strengths and limitations of the studies assessing non-infrastructure hygiene interventions. In our review, we have examined the strengths and limitations of studies specifically focusing on hygiene interventions to further assess the methodological rigour of each study and establish future research needs.

Among the experimental studies summarised in table 1 those that used randomisation were more likely to produce study groups with similar unmeasured baseline characteristics. Those included five studies conducted in child-care centres ${ }^{6,11,15,24,33,34}$ and three conducted at the community level., ${ }^{912,20}$ For most of the studies summarised in table 1, randomisation was not an option. For example, Ahmed et $\mathrm{al}^{18}$ reported that randomisation was not feasible because the educational intervention was too complicated to randomise to multiple groups rather than assigning the intervention to a single geographic area. In intervention studies that use quasi-experimental designs (ie, without randomisation), it is possible that the group assignment may be determined by the desired outcome. For example, the study investigator may assign the intervention to the community that will benefit the most from the intervention as measured by the higher baseline incidence of infectious disease or lower quality of hygiene. In the non-randomised study by Ahmed et $a l,{ }^{18}$ the intervention was implemented in the community that had lower standards of environmental hygiene. As opposed to randomised experimental studies, such quasiexperimental designs have a greater potential for biased results from imbalances in unmeasured baseline risk factors.

One of the greatest difficulties in all studies concerning hygiene practices and infection is controlling for potential confounding variables. For example, if a study did not control for age and included adults as well as young children, the effect of a given hygiene intervention may be diluted since adults are at lower risk for diarrhoeal disease than children. Khan et $\mathrm{al}^{7}$ did not control for age in their study and found a significant reduction in Shigella flexneri infections but not for Shigella dysenteriae. Therefore, their findings of no reduction in $S$ dysenteriae may be the result of including adults in the analysis. Other uncontrolled confounding factors may exaggerate the effects of a given personal hygiene intervention, such as comparing a rural versus urban area. In the study by Ahmed et $\mathrm{al}^{18}$ it was determined that the intervention site was more rural than the control area. This difference in baseline characteristics was not controlled for in the analysis and may have exaggerated the reduction in the rates of infection between the two areas.

In many of the studies in tables 1 and 2, especially the more recent ones, efforts were made to control for numerous potential confounding factors. Some of the more recent studies collected and analysed information on more than 20 potential confounding variables. ${ }^{24,31}$ The study by Kotch et $\mathrm{al}^{24}$ also assessed and analysed potential effect modifiers. Nevertheless, possible interaction between risk factors or interventions was rarely discussed or assessed among the studies in this review.

Observational studies must implement rigorous methods to preserve internal validity since the investigator forgoes randomisation and control over the intervention of interest. Thus, the measure and control of confounding and the potential for selection, recall, and other biases need to be rigorously assessed. For example, in the study by Baltazar et al, ${ }^{47}$ the mothers of cases of diarrhoea may have differentially recalled hygiene behaviors. If cases reported more hygiene practices than controls based upon knowledge of their disease status, the results of the study would be biased.

Although blinding can be difficult to implement in studies concerning hygiene since the subjects, observers, and interviewers are usually aware of the intervention status, some of the studies were able to employ blinding and/or alternative methods to reduce knowledge of the intervention. For example, in the study by Haggerty et $\mathrm{al}^{20}$ field workers were blinded to information concerning diarrhoeal illnesses during observational visits for hygiene characteristics of the home environment. Kotch et $\mathrm{al}^{24}$ blinded parents to the intervention status of their child's classroom, since reporting of diarrhoea might be influenced by knowledge of intervention status.

The time frame of the interventions ranged from 10 days to 4 years and most of the studies were done over a 
period of 1 year or less. Hence, information on long-lasting health effects attributable to the hygiene interventions is unavailable. It could be that after a certain period of time the intervention wanes and is no longer useful, or it may take a longer time to be accepted and the benefits may be underestimated by a shorter time frame. ${ }^{59}$

Some of the studies may have been limited by lack of statistical power. In some cases, the sample sizes may have been too small to detect a significant reduction in illness and therefore one cannot rule out the potential for sampling error. For example, Roberts et $\mathrm{al}^{34}$ had $80 \%$ power to detect a $25 \%$ reduction in diarrhoea with a background rate of 1.4 infections per child-year at an alpha level of $0 \cdot 05$. Hence, an observed reduction less than $25 \%$ may not be statistically significant due to lack of power.

Although some of the studies are methodologically deficient, it is evident that newer studies are attempting to improve upon older methodologies by implementing more rigorous techniques to examine the relation between hygiene measures and health. For example, in 1994 Kotch et $\mathrm{al}^{24}$ improved upon the methods used by Black et $\mathrm{al}^{6}$ and Bartlett et al. ${ }^{11}$ These improvements included the use of blinding, collecting information on numerous potential confounders and effect modifiers, using statistical control for confounders and examining effect modifiers, and using classroom as the unit of observation to avoid analysing multiple diarrhoea episodes in one child as a nonindependent occurrence.

By listing the strengths and limitations of the intervention studies, it is apparent that some of the more pervasive limitations are a consequence of the nature of the relation between hygiene and health. For example, it is often difficult to conduct blinded studies in many settings and it may not be logistically feasible to randomise. In addition, the infectious nature of agents transmitted by the faecal-oral and direct contact routes may render the statistical assumption of non-independence with respect to outcome, which is required for most of the commonly used analytical methods, untenable. Lastly, the identification of certain infections, such as respiratory and diarrhoeal illnesses, is dependent on the intensity of the infection and characterisation of the symptoms. Therefore, infections with limited symptoms may be under-reported as a consequence of the classification of the illness in a given study.

While there continues to be opportunities for ongoing improvements in health through hygienic measures, there is also recent discussion of a negative side to hygiene. Increasing evidence of an inverse correlation between the prevalence of certain infections during infancy and childhood and rates of allergy and atopic disease, termed the "hygiene hypothesis", has raised questions about whether there may be a limit to how clean we should be. Recent studies have linked allergic conditions with factors such as some infectious diseases (hepatitis A, measles, upper respiratory infections), vaccines, and antibiotic use in infancy. ${ }^{47-73}$ This hypothesis is intriguing and will continue to be a rich arena for research.

\section{Search strategy and selection criteria}

This is described in detail in the text.

\section{Limitation of the study review methods}

We did not include studies that were published in languages other than English. In addition, Medline was the only database used. However, we did include two articles that were not published in peer-reviewed journals but were referenced by other articles included in this review. ${ }^{8,37}$

\section{Future research needs}

Although it is evident that improvements in hygiene practices and facilities have played a major part in the prevention of infectious disease over the past 20 years, there is still the need for new and more rigorous future research. First, internal validity issues should be considered in the study design, implementation, and analysis. Baseline potential confounding factors in each study population must be thoroughly characterised to examine the incremental benefits, whether on an individual or group level, of specific personal and environmental hygiene interventions. In addition, potential interactions between intervention methods or risk factors should be assessed. Some of the studies that used different levels of hygiene interventions demonstrated a biological gradient, although examination of a dose-response relation was surprisingly limited in this sample of the literature. Lastly, research into the long-range sustainability of reduction in infections attributed to personal and environmental hygiene interventions should be examined in various high-risk settings.

\section{Conclusions}

Despite methodological strengths and limitations, the weight of evidence from the studies discussed above collectively suggests that personal and environmental hygiene reduces the spread of infection. The consistent findings in both the intervention and observational studies support the conclusion that hygiene interventions other than infrastructure implementation are important for preventing infections. While these results may not be surprising or "new", they are nevertheless impressive and important because they demonstrate that even in an era of unprecedented "cleanliness" and improved public health infrastructure, there is a continued, measurable, positive effect of personal and community hygiene. However, attributing a specific hygiene intervention to a reduction in illness is difficult since it is virtually impossible to isolate the effects of specific hygiene measures. Therefore, the magnitude of reduction in illnesses attributed to a specific intervention or practice alone cannot be assessed. The strength of the association as measured by the relative reduction in risk of illness was appreciable and generally greater than $20 \%$ for most of the hygiene interventions.

\section{Acknowledgement}

We gratefully acknowledge financial support from the Soap and Detergent Association in preparation of this manuscript. This review is an updated, revised, and extended version of: Larson EL, Aiello AE. Hygiene and health: an epidemiologic link? Am J Infect Control 2001; 29: $231-38$. 


\section{References}

1 World Health Organization. The global water supply and sanitation assessment 2000. Geneva: WHO, 2000: 74

2 Esrey SA, Feachem RG, Hughes JM. Interventions for the control of diarrhoeal diseases among young children: improving water supplies and excreta disposal facilities. Bull World Health Organ 1985; 63: 757-72.

3 Esrey SA, Habicht JP. Epidemiologic evidence for health benefits from improved water and sanitation in developing countries. Epidemiol Rev 1986; 8: 117-28.

4 Esrey SA, Potash JB, Roberts L, Shiff C. Effects of improved water supply and sanitation on ascariasis, diarrhoea, dracunculiasis, hookworm infection, schistosomiasis, and trachoma. Bull World Health Organ 1991; 69: 609-21.

5 Curtis V, Cairncross S, Yonli R. Domestic hygiene and diarrhoea pinpointing the problem. Trop Med Int Health 2000; 5: 22-32.

6 Black RE, Dykes AC, Anderson KE, et al. Handwashing to prevent diarrhea in day-care centers. Am J Epidemiol 1981; 113: 445-51.

7 Khan MU. Interruption of shigellosis by hand washing. Trans R Soc Trop Med Hyg 1982; 76: 164-68.

8 Torun B. Environmental and education interventions against diarrhea in Guatemala. New York: Plenum Press, 1982.

9 Stanton BF, Clemens JD. An educational intervention for altering water-sanitation behaviors to reduce childhood diarrhea in urban Bangladesh. II. A randomized trial to assess the impact of the intervention on hygienic behaviors and rates of diarrhea. Am J Epidemiol 1987; 125: 292-301.

10 Hill JM, Woods ME, Dorsey SD. A human development intervention in the Philippines: effect on child morbidity. Soc Sci Med 1988; 27: $1183-88$.

11 Bartlett AV, Jarvis BA, Ross V, et al. Diarrheal illness among infants and toddlers in day care centers: effects of active surveillance and staff training without subsequent monitoring. Am J Epidemiol 1988; 127: 808-17.

12 Han AM, Hlaing T. Prevention of diarrhoea and dysentery by hand washing. Trans R Soc Trop Med Hyg 1989; 83: 128-31.

13 Alam N, Wojtyniak, B, Henry FJ, Rahaman MM. Mothers' personal and domestic hygiene and diarrhoea incidence in young children in rural Bangladesh. Int J Epidemiol 1989; 18: 242-47.

14 Aziz KM, Hoque BA, Hasan KZ, et al. Reduction in diarrhoeal diseases in children in rural Bangladesh by environmental and behavioural modifications. Trans R Soc Trop Med Hyg 1990; 84 433-38.

15 Butz AM, Larson E, Fosarelli P, Yolken R. Occurrence of infectious symptoms in children in day care homes. Am J Infect Control 1990; 18: 347-53.

16 Wilson JM, Chandler, GN, Muslihatun J. Hand-washing reduces diarrhoea episodes: a study in Lombok, Indonesia. Trans $R$ Soc Trop Med Hyg 1991; 85: 819-21.

17 Monsma M, Day R, St. Arnaud S. Handwashing makes a difference. J Sch Health 1992; 62: 109-11.

18 Ahmed NU, Zeitlin MF, Beiser AS, Super CM, Gershoff SN. A longitudinal study of the impact of behavioural change intervention on cleanliness, diarrhoeal morbidity and growth of children in rural Bangladesh. Soc Sci Med 1993; 37: 159-71.

19 Araya M, Espinoza J, Brunser O, Cruchet S. Effect of health education and primary care on diarrhoeal disease morbidity in children: evaluation of a predictive intervention model. J Diarrhoeal Dis Res 1994; 12: 103-07.

20 Haggerty PA, Muladi K, Kirkwood BR, Ashworth A, Manunebo M. Community-based hygiene education to reduce diarrhoeal disease in rural Zaire: impact of the intervention on diarrhoeal morbidity. Int J Epidemiol 1994; 23: 1050-9.

22 West S, Munoz B, Lynch M, et al. Impact of face-washing on trachoma in Kongwa, Tanzania. Lancet 1995; 345: 155-58.

23 Mohle-Boetani JC, Stapleton M, Finger R, et al. Communitywide shigellosis: control of an outbreak and risk factors in child day-care centers. Am J Public Health 1995; 85: 812-16.

24 Kotch JB, Weigle KA, Weber DJ, et al. Evaluation of an hygienic intervention in child day-care centers. Pediatrics 1994; 94: 991-94.

25 Pinfold JV, Horan NJ. Measuring the effect of a hygiene behaviour intervention by indicators of behaviour and diarrhoeal disease. Trans $R$ Soc Trop Med Hyg 1996; 90: 366-71.

26 Krilov LR, Barone SR, Mandel FS, Cusack TM, Gaber DJ, Rubino JR. Impact of an infection control program in a specialized preschool. Am J Infect Control 1996; 24: 167-73.

24 Shahid NS, Greenough WB, 3rd, Samadi AR, Huq MI, Rahman N. Hand washing with soap reduces diarrhoea and spread of bacterial pathogens in a Bangladesh village. J Diarrhoeal Dis Res 1996; 14: 85-9.
27 Kimel LS. Handwashing education can decrease illness absenteeism. J Sch Nurs 1996; 12: 14-16.

28 Niffenegger JP. Proper handwashing promotes wellness in child care. J Pediatr Health Care 1997; 11: 26-31.

29 Master D, Hess Longe SH, Dickson H. Scheduled hand washing in an elementary school population. Fam Med 1997; 29: 336-39.

30 Peterson EA, Roberts L, Toole MJ, Peterson DE. The effect of soap distribution on diarrhoea: Nyamithuthu Refugee Camp. Int $J$ Epidemiol 1998; 27: 520-24.

31 Carabin H, Gyorkos TW, Soto JC, Joseph L, Payment P, Collet JP. Effectiveness of a training program in reducing infections in toddlers attending day care centers. Epidemiology 1999; 10: 219-27.

32 Falsey AR, Criddle MM, Kolassa JE, McCann RM, Brower CA, Hall WJ. Evaluation of a handwashing intervention to reduce respiratory illness rates in senior day-care centers. Infect Control Hosp Epidemiol 1999; 20: 200-22.

33 Roberts L, Smith W, Jorm L, Patel M, Douglas RM, McGilchrist C. Effect of infection control measures on the frequency of upper respiratory infection in child care: a randomized, controlled trial. Pediatrics 2000; 105: 738-42.

34 Roberts L, Jorm L, Patel M, Smith W, Douglas RM, McGilchrist C. Effect of infection control measures on the frequency of diarrheal episodes in child care: a randomized, controlled trial. Pediatrics 2000; 105: 743-46.

35 Dyer DL, Shinder A, Shinder F. Alcohol-free instant hand sanitizer reduces elementary school illness absenteeism. Fam Med 2000; 32: 633-38.

36 Bertrand WE, Walmus BF. Maternal knowledge, attitudes and practice as predictors of diarrhoeal disease in young children. Int J Epidemiol 1983; 12: 205-10.

37 Stanton B, Clemens J. Practices differing between families with high and low rates of diarrhea. 25th meeting of the Interscience Conference on Antimicrobial Agents and Chemotherapy (ICAAC); 1985; Minneapolis, MN.

38 Baltazar JC, Solon FS. Disposal of faeces of children under two years old and diarrhoea incidence: a case-control study. Int Jof Epidemiol 1989; 18: S16-19.

39 Taylor HR, West SK, Mmbaga BB, et al. Hygiene factors and increased risk of trachoma in central Tanzania. Arch Ophthalmol 1989; 107: 1821-25.

40 Henry FJ, Rahim Z. Transmission of diarrhoea in two crowded areas with different sanitary facilities in Dhaka, Bangladesh. J Trop Med Hyg 1990; 93: 121-26.

41 Yeager BA, Lanata CF, Lazo F, Verastegui H, Black RE. Transmission factors and socioeconomic status as determinants of diarrhoeal incidence in Lima, Peru. J Diarrhoeal Dis Res 1991; 9: 186-93.

42 West SK, Congdon N, Katala S, Mele L. Facial cleanliness and risk of trachoma in families. Arch Ophthalmol 1991; 109: 855-57.

43 Ekanem EE, Akitoye CO, Adedeji OT. Food hygiene behaviour and childhood diarrhoea in Lagos, Nigeria: a case-control study. J Diarrhoeal Dis Res 1991; 9: 219-26.

44 Moy RJ, Booth IW, Choto RG, McNeish AS. Risk factors for high diarrhoea frequency: a study in rural Zimbabwe. Trans $R$ Soc Trop Med Hyg 1991; 85: 814-18.

45 Wijewardene K, Fonseka P, Wijayasiri WA. Risk factors contributing to acute diarrhoeal disease in children below five years. Ceylon Med J 1992; 37: 116-19.

46 Bartlett AV, Hurtado E, Schroeder DG, Mendez H. Association of indicators of hygiene behavior with persistent diarrhea of young children. Acta Paediatr Suppl 1992; 381: 66-71.

47 Baltazar JC, Tiglao TV, Tempongko SB. Hygiene behaviour and hospitalized severe childhood diarrhoea: a case-control study. Bull World Health Organ 1993; 71: 323-28.

48 Punyaratabandhu P, Sangchai R, Vathanophas K, Athipanyakom S, Varavithya W. Risk factors for childhood diarrhea in an urban community, Bangkok, Thailand. J Med Assoc Thai 1993; 76: 535-41.

49 Dikassa L, Mock N, Magnani R, et al. Maternal behavioural risk factors for severe childhood diarrhoeal disease in Kinshasa, Zaire. Int J Epidemiol 1993; 22: 327-33.

50 Sempertegui F, Estrella B, Egas J, et al. Risk of diarrheal disease in Ecuadorian day-care centers. Pediatr Infect Dis J 1995; 14: 606-12.

51 Rudland S, Little M, Kemp P, Miller A, Hodge J. The enemy within: diarrheal rates among British and Australian troops in Iraq. Mil Med 1996; 161: 728-31.

52 Ghosh S, Sengupta PG, Mondal SK, Banu MK, Gupta DN, Sircar BK. Risk behavioural practices of rural mothers as determinants of childhood diarrhoea. J Commun Dis 1997; 29: 7-14. 
53 Oyemade A, Omokhodion FO, Olawuyi JF, Sridhar MK, Olaseha IO. Environmental and personal hygiene practices: risk factors for diarrhoea among children of Nigerian market women. J Diarrhoeal Dis Res 1998; 16: 241-47.

54 St Sauver J, Khurana M, Kao A, Foxman B. Hygienic practices and acute respiratory illness in family and group day care homes. Public Health Rep 1998; 113: 544-51.

55 Gorter AC, Sandiford P, Pauw J, Morales P, Perez RM, Alberts H. Hygiene behaviour in rural Nicaragua in relation to diarrhoea. Int of Epidemiol 1998; 27: 1090-100.

56 Barros AJ, Ross DA, Fonseca WV, Williams LA, Moreira-Filho DC. Preventing acute respiratory infections and diarrhoea in child care centres. Acta Paediatr 1999; 88: 1113-18.

57 Scolari C. Prevalence and distribution of soil-transmitted helminth (STH) infections in urban and indigenous schoolchildren in ortigueira, state of Parana, brasil: implications for control. Trop Med Int Health 2000; 5: 302-07.

58 Pruss A, Mariotti SP. Preventing trachoma through environmental sanitation: a review of the evidence base. Bull World Health Organ 2000; 78: 258-66.

59 Feachem RG. Sanitation and disease: Health aspects of excreta and wastewater management. New York: John Wiley \& Sons, 1983.

60 Matricardi PM, Bonini S. High microbial turnover rate preventing atopy: a solution to inconsistencies impinging on the hygiene hypothesis? Clin Exp Allergy 2000; 30: 1506-10.

61 Holt PG. Parasites, atopy, and the hygiene hypothesis: resolution of a paradox? Lancet 2000; 356: 1699-701.

62 Bodner C, Anderson WJ, Reid TS, Godden DJ. Childhood exposure to infection and risk of adult onset wheeze and atopy. Thorax 2000; 55: 383-87.

63 Wickens K, Pearce N, Crane J, Beasley R. Antibiotic use in early childhood and the development of asthma. Clin Exp Allergy 1999; 29: 766-71.

64 Kemp T, Pearce N, Fitzharris P, et al. Is infant immunization a risk factor for childhood asthma or allergy? Epidemiology 1997; 8: 678-80.

65 Aaby P, Shaheen SO, Heyes CB, et al. Early BCG vaccination and reduction in atopy in Guinea-Bissau. Clin Exp Allergy 2000; 30: 644-50.

66 Illi S, von Mutius E, Lau S, et al. Early childhood infectious diseases and the development of asthma up to school age: a birth cohort study. BMJ 2001; 322: 390-5.

67 Kleinert S. The hygiene hypothesis gains further momentum in childhood asthma. Lancet 2000; 356: 1699-700.

68 Alm JS, Swartz J, Lilja G, Scheynius A, Pershagen G. Atopy in children of families with an anthroposophic lifestyle. Lancet 1999; 353: $1485-88$.

69 Golding J, Peters T. Eczema and hay fever. In: Butler NR, Golding J, eds. From birth to five: a study of the health and behaviour of Britain's five year olds. Oxford: Pergamon Press, 1986: 171-86.

70 Matricardi PM, Rosmini F, Ferrigno L, et al. Cross sectional retrospective study of prevalence of atopy among Italian military students with antibodies against hepatitis A virus. BMJ 1997; 314: 999-1003.

71 Nilsson L, Kjellman NI, Bjorksten B. A randomized controlled trial of the effect of pertussis vaccines on atopic disease. Arch Pediatr Adolesc Med 1998; 152: 734-38.

72 Shaheen SO, Aaby P, Hall AJ, et al. Measles and atopy in GuineaBissau. Lancet 1996; 347: 1792-96.

73 von Hertzen L, Klaukka T, Mattila H, Haahtela T. Mycobacterium tuberculosis infection and the subsequent development of asthma and allergic conditions. J Allergy Clin Immunol 1999; 104: 1211-14.

Extended versions of tables 1 and 2 are available in pdf format on The Lancet Infectious Diseases website, http://infection.thelancet.com 